\title{
Evaluations of Some Biological Properties of Ethanolic Leave Extract of Costus Afer (Ker Gawl).
}

\author{
Ezejiofor A. $\mathrm{N}^{1}$, Igweze $\mathrm{Z}^{2}$, Amadi C. $\mathrm{N}^{1}$ \\ ${ }^{I}$ Department of Experimental Pharmacology \& Toxicology.Faculty of Pharmaceutical Sciences, University of \\ Port Harcourt, Rivers State, Nigeria. \\ ${ }^{2}$ Department of Pharmacology, Madonna University, Elele, Rivers State, Nigeria.
}

\begin{abstract}
Costus afer plant has been known to the traditionalist for a very long time. The locals having realized its medicinal potentials have employed it in a variety of ways. This study was designed to investigate the antimicrobial, biochemical and CNS depressant properties of ethanolic leave extract of Costus afer in albino mice and anti-inflammatory activity in albino rats. Ninety albino mice (22-29g) of both sexes were selected and divided into eighteen groups of five mice each. Four groups for analgesic activity, three groups for in-vivo clothing time, four groups for spontaneous locomotor activity, three groups for heamatological evaluation and four groups for phenobarbitone induced hypnosis. Twenty albino rats (180-200g) of both sexes were also selected and divided into four groups of five rats each and used for anti-inflammatory activity. In all, the control groups receive $0.2 \mathrm{ml}$ of normal saline while two dose groups of the extract was used 400 and $1200 \mathrm{mg} / \mathrm{kg}$ representing low and high dose in the treatment group. Indomethacin, Phenobarbitone, Chropromazine, Indomethacine, Ciprofloxacin and Fluconazole were used as reference drug for anlagesic activity, locomotor activity, hypnosis, anti-inflammatory, antibacterial and antifungal test respectively. Qualitative phytochemical analysis of ethanolic leave extract of Costus afer was performed. The result of the qualitative phytochemical analysis revealed the presence of alkaloids, saponins, flavonoids, tannins, phenols, glycosides and terpenoids whereas anthraquinones, essential oil and phlobatannins were absent. The results obtained shows that ethanolic leave extract of Costus afer posses antibacterial activity but no antifungal activity. There was a dose dependent increase in analgesic, anti-inflammatory activities, bleeding/clotting time and CNS activity. The hematological evaluation of the leaves of costusafer shows that the extract has no noticeable effect on the $H B$, $P C V, R B C$, but decreases the WBC, platelet count, neutrophils and lymphocytes components of the blood, also the clotting/bleeding time was seen to increase dose dependently in the treated groups. In conclusion, ethanol extract of costus afer ker Gawl leaves possess antimicrobial, analgesic, anti-inflammatory and CNS depressant activity.
\end{abstract}

Keywords: biological, ethanol extract, Costus afer, anti-inflammatory, clotting time.

\section{Introduction}

The plant kingdom in particular has proven to be the most successful in the treatment of nearly all ailments and they also provide an important source of raw materials for the world's pharmaceutical. Nearly all cultures from the old to the present day have used plants as sources of medicines and the number is on the increase due to the escalating cost and toxic complications of sophisticated medical care. Plant has always played a major role in the treatment of human traumas and diseases. Medicinal plant according to WHO (1977) has been described as any plant which, in one or more of its organs, contains substances that can be used for therapeutic purposes or which are precursors for the synthesis of useful drugs. Natural products lack defined dose and potency data, they also benefit from containing many specific molecular principles in their natural state, which posses a variety of influence on human biochemical and physiological processes, as opposed to purified and synthetic drugs which are based on a single molecular substance derived from the natural product (Taylor et al .,2001) .

Costus afer as a medicinal plant is commonly used for traditional therapeutic and social cultural purposes. Costus afer is a perennial herbaceous plant in the family Costaceae. There are various species of Costus, some of which are Costus alleni, Costus spectabilis(the floral emblem of Nigeria) Costus amazonicus, Costus barbatus, Costus beckii, Costus spectabilis, Costus afer etc (Iwu, 1983). Costus afer generally known as ginger lilly or bush cane is a herb of many medicinal use both documented and undocumented (Oliver, et al, 1960).This present investigation of ethanolic leave extract of Costus afer was carried out to ascertain its antiinflammatory, anti-microbial, anti-hemorrhagic, anti-nociceptive and CNS properties which probably can be inclined to multi-molecular principles found mostly in the natural state of herbs which also conform with its multi-action. 
Sample collection

\section{Materials And Methods}

The leaves of Costus afer were collected from Aluu in Obiakpor Local Government area of Rivers State, Nigeria in October, 2015.

Sample identification

\section{Sample processing and extraction}

After identification, the samples were washed with clean tap water to remove dirt on the leaves. After which the leaves were kept in a mesh and allow water to drain off, it was then cut in small sizes with stainless steel knife and dried under shade, the dried leaves were then grinded to obtain a fine powder using electric grinder.

\section{Extraction}

Six hundred grams $(600 \mathrm{~g})$ of the grinded Costus afer leave powder were weighed and macerated in 2.5litres of ethanol in a stoppered container and allowed to stand for 48hours with constant agitation. After 48hours, the mixture was strained, the marc pressed and the liquid filtered using what man filter paper. The filtrate was allowed to evaporate using water bath set at $45^{\circ} \mathrm{c}$.

\section{Phytochemical screening}

Basic phytochemical screening was carried out to detect the presence of tannins, saponins, anthraquinones, alkaloids, and other phenolic compounds in accordance with the standards methods of Harbone, (1998); Trease and Evans, (2009); Sofowora,(2006).

\section{Test for alkaloids}

About $5 \mathrm{mls}$ of the extract was stirred with $5 \mathrm{mls}$ of $1 \%$ aq. $\mathrm{HCl}$ on a water bath. $1 \mathrm{ml}$ of the filtrate was treated with a few drops of Mayer`s reagent (Mercuric iodide solution) and the second $1 \mathrm{ml}$ portion was treated similarly with Drangendorffs reagent (iodine in KI solution). Cream and orange colour observed indicated the presence of alkaloids (Soforowa, 2006).

Test for flavonoids:

Dilute sodium hydroxide $(\mathrm{NaOH})$ was added to $1 \mathrm{ml}$ of the extract, a yellow colour on addition of HCL confirms the presence of flavonoids (Trease and Evans, 2009).

\section{Test for tannins:}

$5 \mathrm{mls}$ of plant extract was stirred with $2 \mathrm{mls}$ of distilled water, filtered and $\mathrm{FeCl}_{3}$ reagent added to the filtrate. A blue-black, green, blue-green precipitate is evidence of the presence of tannins (Trease and Evans, 2009).

Test for saponins:

The frothing test method of Wall et al (1952 and 1954) was adopted here. $2.5 \mathrm{mls}$ of the extract was shaken with water in a test tube. Frothing which persists on warming was taken as preliminary evidence for the presence of saponins.

Test for glycosides: Test Salkowski test described by Sofowora (2006) was used here. $2 \mathrm{mls}$ of chloroform was added to $5 \mathrm{ml}$ of extract. $\mathrm{H}_{2} \mathrm{SO}_{4}$ was carefully added to form a lower layer. A reddish brown colour at the interface indicates the presence of a steroidal ring which is a glycone portion of a cardiac glycoside.

\section{Test for phenols:}

$2 \mathrm{mls}$ of dilute $\mathrm{NaOH}$ was added to $5 \mathrm{mls}$ of extract. A bluish colour indicates the presence of phenolic compound.

\section{Test for terpenoids:}

$5 \mathrm{mls}$ of extract was mixed in $2 \mathrm{ml}$ of chloroform. $3 \mathrm{ml}$ of concentrated $\mathrm{H}_{2} \mathrm{SO}_{4}$ was added to form a layer. A reddish-brown precipitate colouration at the interface formed indicated the presence of terpenoids.

\section{Animals Care And Handling}

Ninety Albino mice with weight range 18-30g and twenty albino rats with weight range 160-290g used for this study were obtained from the animal house of Department of Pharmacology and Toxicology, University of Port Harcourt, Rivers State, Nigeria. The animals were placed in standard cages and housed in a controlled environment for at least two weeks for acclimatization. Animal ethics and proper handling methods were strictly adhered to. The cages were cleaned daily, ensuring proper and adequate bedding using saw dust. The animals were fed daily with their standard diets; and water ad libitium.

Experimental Protocol:

DRUGS: the following drugs were used for the experiment

- Phenobarbitone (phenobarb ${ }^{\mathrm{R}}$ ), Swipha Pharm, Nigeria Ltd..

- Chlorpromazine (Thorazine ${ }^{\mathrm{R}}$ ), $\mathrm{SKG}$-Pharma. Ltd, Lagos, Nigeria.

- Indomethacin (indomet ${ }^{\mathrm{R}}$ ), Neimeth International Pharma. Plc.

- Albumin (egg).

Phenobarbitone induced hypnosis 
The test as described by Dandiya and Columbine (1991) was adopted. Twenty albino mice were starved for 24hours prior to drug administration. The animals were divided into four groups of five animals each to serve as control, reference, and the test group. The control group received $0.2 \mathrm{ml}$ of normal saline. The reference group received $10 \mathrm{mg} / \mathrm{kg}$ chlorpromazine, while the other two groups received $400 \mathrm{mg} / \mathrm{kg}$ and $1200 \mathrm{mg} / \mathrm{kg}$ of the extract per oral respectively. All the animals were then injected $20 \mathrm{mg} / \mathrm{kg}$ (i.p) of phenobarbitone after 30minutes. The duration of loss and gain of righting was taken as measure of sleeping time and was recorded (Ezejiofor, et al 2011).

\section{Spontanouslocomotor activity}

The test as described by Saluja and Santani (Saluja and Santani, 1994) was adopted with little modification. Twenty (20) albino mice were divide into four different groups namely control, reference and test groups respectively. The control group received $0.2 \mathrm{ml}$ of normal saline, reference group received $20 \mathrm{mg} / \mathrm{kg}$ phenobarbitone and the test groups received $400 \mathrm{mg} / \mathrm{kg}$ and $1200 \mathrm{mg} / \mathrm{kg}$ doses of the extract. The animals were observed for movement, gait, scratching rate and tactile responses 30 minutes after treatment and at 30 minutes interval for 120 minutes (Ezejiofor, et al 2011).

\section{Anti-inflammatory activity}

Pedal inflammation in albino rats (180-200g) of either sex was produced according to the method described by Winter et al (1972) .Twenty (20) albino rats were starved for 24hours before drug administration. Animals were divided into four groups of five rats each which serves as the control, reference and test group respectively. Animals were given test agents intraperitoneally 30minutes before the albumin injection. The reference group received $5 \mathrm{mg} / \mathrm{kg}$ indomethacin, the control group received $0.2 \mathrm{ml}$ of normal saline while the test group received $400 \mathrm{mg} / \mathrm{kg}$ and $1200 \mathrm{mg} / \mathrm{kg}$ of the test extract. Increase in paw circumference which is an index of increase in paw volumes, and a measure of edema was measured. Measurements were taken immediately before and at 30 minutes interval for 2 hours after albumin injection (Ezejiofor, et al 2011).

The inhibitory activity was calculated using the formula [Ezejiofor et al., 2011]

$\%$ inhibition $=(\mathrm{Ct}-\mathrm{Co})$ control $-(\mathrm{Ct}-\mathrm{Co})$ treated

$$
\text { (Ct-Co) control x } 100
$$

$\mathrm{Ct}=$ linear circumference of paw after injection

$\mathrm{Co}=$ linear circumference of paw before injection

\section{Heamatological evaluation}

Fifteen (15) albino mice each with a weight ranging from $22-28 \mathrm{~g}$ were divided into three groups. The control group received $0.2 \mathrm{ml}$ of normal saline for five (5) days while the test groups received $400 \mathrm{mg} / \mathrm{kg}$ and $1200 \mathrm{mg} / \mathrm{kg}$ of Costus afer extract for five (5) days. On the six (6) day about $2 \mathrm{mls}$ of blood was withdrawn from the animals into heparinized tubes and evaluated for the packed cell volume (PVC), white blood cell (WBC) and differential, red blood cell (RBC) and hemoglobin concentration (Ezejiofor, et al 2011).

\section{In-vivo clotting time}

In vivo clotting time was also determined. On the second day, the animal tail was cut with a sharp stainless blade and the time taken for the bleeding to stop was taken as a measure of clotting time.

\section{Anti-nociceptive TEST (TAIL FLICK METHOD)}

Analgesia was measured using modified method of Amour and Smith (1998) called tail flick method analgesiometer. Twenty (20) albino mice weighing 22-25g were divided into groups. Reaction time in seconds was used as the unit for measurement of pain and an increase reaction time was indicative of analgesia. The time between placing the tail of the mice on the radiant heat and sharp withdrawal of the tail was recorded as reaction time. Cut off time of 20 seconds was imposed of experiments taken as maximum latency so as to rule out thermal injury. In all groups, tail-flick test was performed prior to drug administration and at 30, 60, 90 and 120 minutes after indomethacin and extract administration.

\section{Antibiotic susceptibility testing (agar diffusion test)}

The work bench was disinfected using a disinfectant. A $0.1 \mathrm{ml}$ culture of the Escherichia coli was added into the nutrient agar pour in the universal bottle already prepared and mixed properly. The content of the mixture was poured into a sterile petri dish and allowed to solidify on the bench. A sterile cork borer was used to remove two discs of agar from the agar layer in order to produce two wells in the agar plate. One drop of $50 \mathrm{mg}$ per $\mathrm{ml}$ of ciprofloxacin (reference drug) was added carefully using a sterile pasta pipette into one of the wells in the agar plate and one drop of $6 \mathrm{mg}$ per $\mathrm{ml}$ of the Costus afer extract was added into the second well in the agar plate. The following procedure was repeated using Psuedomonas aeruginosa and staphylococcus aureus using ciprofloxacin as a reference drug. The procedure was also repeated using Candida albican in which sabouraud dextrose agar (SDA) was used as the medium and fluconazole was used as the reference drug. All the plates were allowed on the bench at room temperature for 15 minutes for proper diffusion of the antibiotics. The plates containing Escherichia coli, Pseudomonas aeruginosa and staphylococcus aureus where incubated at $37^{\circ} \mathrm{C}$ for 24 hours while the plate containing Candida albican was incubated at $37^{\circ} \mathrm{C}$ for 48 hours. 
The diameter of any resulting zone of inhibition in millimeters $(\mathrm{mm})$ through the base of the plate was measured (Ezejiofor, et al 2011).

Statistical analysis:

The data was analysed using one-way analysis of variance (ANOVA) followed by students t-test using Graph pad prism 6.

III. Results

Table 1: Phytochemical analysis of ethanol extract of costus afer leave.

\begin{tabular}{|l|l|}
\hline Compound & Inference \\
\hline Alkaloids & + \\
\hline Flavonoids & + \\
\hline Tannins & + \\
\hline Saponins & + \\
\hline Glycosides & + \\
\hline Phenols & + \\
\hline Terpenoids & + \\
\hline Anthraquinones & - \\
\hline Essential oil & - \\
\hline Phlobatannins & - \\
\hline
\end{tabular}

Table 2: Antimicrobial Susceptibility Testing of Ethanol Leaf Extract of Costus afer.

\begin{tabular}{|l|l|l|l|}
\hline Organisms & $\begin{array}{l}\text { Average Inhibition zone diameter } \\
\text { of Costus afer extract (mm) }\end{array}$ & $\begin{array}{l}\text { Average Inhibition zone diameter } \\
\text { of reference drug }(\mathrm{mm})\end{array}$ & $\begin{array}{l}\text { Average Inhibition zone } \\
\text { diameter of reference drug (mm) }\end{array}$ \\
\hline E. coli & 14.5 & 18.5 & \\
\hline P.aeruginosa & 5.1 & 11.5 & \\
\hline Staph.aureus & 26.5 & 36 & 24 \\
\hline C. albican & - & - & \\
\hline
\end{tabular}

Keys E. coli = Escherichia coli, P.aeruginosa = Pseudomonas aeruginosa, Staph. aureus = Staphylococcus aureus, C. albican $=$ Candida albican

Table 3 Analgesic activity of the ethanolic extract of Costus afer leaf.

\begin{tabular}{|l|c|l|l|l|l|}
\hline & \multicolumn{5}{|c|}{ Reaction time(seconds) } \\
\hline Groups & 0 & 1800 & 3600 & 5400 & 7200 \\
\hline Control & $4.42 \pm 0.45$ & $4.44 \pm 0.25$ & $4.38 \pm 0.24$ & $4.60 \pm 0.41$ & $4.48 \pm 0.29$ \\
\hline Reference (indomethacin) & $4.58 \pm 0.33$ & $9.24 \pm 0.84$ & $13.64 \pm 1.77$ & $17.28 \pm 1.88$ & $19.18 \pm 1.86$ \\
\hline $\begin{array}{l}\text { Costus afer leaf } \\
400 \mathrm{mg} / \mathrm{kg}\end{array}$ & $4.56 \pm 0.29$ & $5.72 \pm 0.99$ & $6.48 \pm 1.09$ & $7.84 \pm 1.17$ & $10.48 \pm 1.55$ \\
\hline $\begin{array}{l}\text { Costus afer leaf } \\
1200 \mathrm{mg} / \mathrm{kg}\end{array}$ & $5.0 \pm 0.19$ & $8.12 \pm 0.17$ & $11.5 \pm 1.10$ & $15.44 \pm 0.70$ & $16.0 \pm 0.59$ \\
\hline
\end{tabular}

All values represents as mean reaction time $\pm \mathrm{SD},(n=5)$. The data was analyzed using one-way analysis of variance (ANOVA) followed by students t-test using Graph pad prism 6.

Table 4: the anti-inflammatory activity/ Percent Inhibition (\%)

\begin{tabular}{|c|c|c|c|c|c|}
\hline Groups & \multicolumn{5}{|c|}{ Paw size $(\mathbf{m m}) /$ time(minutes) } \\
\hline & 0 & 30 & 60 & 90 & 120 \\
\hline Control & $5.27 \pm 0.08$ & $5.31 \pm 0.084$ & $5.31 \pm 0.073$ & $5.30 \pm 0.061$ & $5.28 \pm 0.059$ \\
\hline Reference & $5.28 \pm 0.051$ & $\begin{array}{l}5.76 \pm 0.15 \\
(26)\end{array}$ & $\begin{array}{l}5.54 \pm 0.13 \\
(48)\end{array}$ & $\begin{array}{l}5.38 \pm 0.091 \\
(10)\end{array}$ & $\begin{array}{l}5.29 \pm 0.040 \\
(1)\end{array}$ \\
\hline $\begin{array}{l}\text { Costus afer leaf } \\
\text { extract } 400 \mathrm{mg} / \mathrm{kg}\end{array}$ & $4.98 \pm 0.079$ & $\begin{array}{l}5.50 \pm 0.16 \\
(52)\end{array}$ & $\begin{array}{l}5.94 \pm 0.34 \\
(96)\end{array}$ & $\begin{array}{l}5.22 \pm 0.38 \\
(24)\end{array}$ & $\begin{array}{l}5.12 \pm 0.084 \\
(14)\end{array}$ \\
\hline $\begin{array}{l}\text { Costus afer leaf } \\
\text { extract } 1200 \mathrm{mg} / \mathrm{kg}\end{array}$ & $4.90 \pm 0.158$ & $\begin{array}{l}5.58 \pm 0.31 \\
(68)\end{array}$ & $\begin{array}{l}5.84 \pm 0.11 \\
(74)\end{array}$ & $\begin{array}{l}4.97 \pm 0.22 \\
\text { (7) }\end{array}$ & $\begin{array}{l}4.90 \pm 0.12 \\
(10)\end{array}$ \\
\hline
\end{tabular}

The above values represents mean paw size \pm SD for five independent observation $(n=5)$ at $0,30,60,90$, and 120 minutes interval respectively.

The table 5:Spontaneous locomotor activity of C.afer in mice. 
Evaluations of Some Biological Properties of Ethanolic Leave Extract of Costus Afer (Ker Gawl).

\begin{tabular}{|c|c|c|c|c|c|c|c|c|c|}
\hline Treatment & Does $(\mathrm{mg} / \mathrm{kg})$ & \multicolumn{2}{|c|}{$30 \mathrm{~min}$} & \multicolumn{2}{|c|}{$60 \min$} & \multicolumn{2}{|c|}{$90 \min$} & \multicolumn{2}{|c|}{$120 \mathrm{~min}$} \\
\hline & & MV & GA & MV & GA & MV & GA & MV & $\mathrm{GA}$ \\
\hline $\mathrm{NC}$ & NS & 3 & 3 & 3 & 3 & 3 & 3 & 3 & 3 \\
\hline Phenobarbitone & 20 & 2 & 2 & 1 & 1 & 1 & 1 & 0 & 0 \\
\hline Costus afer & 400 & 3 & 3 & 3 & 2 & 2 & 1 & 1 & 1 \\
\hline Costus afer & 1200 & 3 & 3 & 2 & 2 & 1 & 1 & 1 & 1 \\
\hline
\end{tabular}

Key/Rating: Movement (mv); $3=$ highly mobile, $2=$ moderately mobile, $1=$ slightly mobile, $0=$ immobile.

Gait (GA); $3=$ highly stable, $2=$ moderately stable, $1=$ slight stable, $0=$ unstable. NS=normal saline.

Table 6: The results of phenobarbitone sleeping time

\begin{tabular}{|l|l|l|l|l|}
\hline Treatment & Dose $(\mathrm{mg} / \mathrm{kg})$ & $\begin{array}{l}\text { Time of loss of } \\
\text { righting Reflex }(\mathrm{min})\end{array}$ & $\begin{array}{l}\text { Time to gain righting } \\
\text { reflex (min) }\end{array}$ & $\begin{array}{l}\text { Sleeping time(minutes) } \pm \text { S.D (time of } \\
\text { gain-time of loss of righting reflex) }\end{array}$ \\
\hline NC & NS & & 10.4 & $10.4 \pm 2.07$ \\
\hline Phenobarbitone & 10 & 14.8 & 175.7 & $160.9 \pm 24.96$ \\
\hline Costus afer & 400 & 10.0 & 26.8 & $16.8 \pm 1.92$ \\
\hline Costus afer & 1200 & 15.7 & 48.1 & $32.4 \pm 8.88$ \\
\hline
\end{tabular}

Values are expressed as mean \pm SD. $(n=5) .1200 \mathrm{mg} / \mathrm{kg}$ extract vs control $=\mathrm{p}<0.05,1200 \mathrm{mg} / \mathrm{kg}$ extract vs reference $=\mathrm{p}<0.05 .400 \mathrm{mg} / \mathrm{kg}$ extract vs control $=<0.05,400 \mathrm{mg} / \mathrm{kg}$ extract vs reference $=<0.05$.

The table 7: results of the hematological evaluation

\begin{tabular}{|c|c|c|c|c|c|c|c|c|c|c|c|}
\hline $\begin{array}{l}\text { Treatment } \\
\text { Dose (mg kg) }\end{array}$ & $\begin{array}{l}\text { Bleeding } \\
\text { Time (Sec.) }\end{array}$ & $\begin{array}{l}\mathrm{HB} \\
\text { (gdil) }\end{array}$ & $\begin{array}{l}\text { PCV } \\
(\%)\end{array}$ & $\begin{array}{l}\mathrm{RBC} \\
\left(\mathrm{x} 10^{1 / 2} \mathrm{~L}\right)\end{array}$ & $\begin{array}{l}\mathrm{WBC} \\
\left(\mathrm{x} 10^{\circ} \mathrm{L}\right)\end{array}$ & $\begin{array}{l}\text { PLATELET } \\
\left(\mathrm{x} 10^{\circ} \mathrm{L}\right)\end{array}$ & \begin{tabular}{|l|} 
NEUTROPH \\
ILS \\
\end{tabular} & $\begin{array}{l}\text { LYMPHOC } \\
\text { YTES }\end{array}$ & $\begin{array}{l}\text { EOSINO } \\
\text { PHIIS }\end{array}$ & $\begin{array}{l}\text { MONOC } \\
\text { YTES }\end{array}$ & \begin{tabular}{|l} 
BASOP \\
HILS \\
\end{tabular} \\
\hline NS & $30.4 \pm 2.07$ & $12.2+1.02$ & $36.6+3.21$ & $5.58+0.50$ & $7.22+0.25$ & $224 \pm 18.16$ & $27.6+2.30$ & $77.6 \pm 2.30$ & & & \\
\hline 400 C.cafer & $39.4 \pm 1.14$ & $12.14+0.93$ & $35.6+1.1 .82$ & $5.38+0.37$ & $6.02 \pm 0.74$ & $181.6+9.33$ & $21.2+1.30$ & $71.4 \pm 1.67$ & & & \\
\hline 1200 C.afer & $50.4 \pm 3.65$ & $12.18+0.78$ & $36.8+1.78$ & $5.64+0.13$ & $4.42+0.27$ & $154.4 \pm 5.60$ & $18.0+1.58$ & $61.2+1.3$ & & & \\
\hline
\end{tabular}

The values above are expressed as mean \pm standard deviation for five independent observation $(n=5) . K e y$ : $\mathrm{Hb}=$ heamoglobin, $\mathrm{PCV}=$ packed cell volume, $\mathrm{RBC}=$ red blood cell, $\mathrm{WBC}=$ white blood cell, $\mathrm{NS}=$ normal saline.

\section{Results:}

Table 1 shows the result of the preliminary phytochemical screening carried out on the ethanol extract of Costus afer leaf. Phytochemicals present include alkaloids, flavonoids, tannins, saponins, glycosides, phenols, and terpenoids whereas anthraquinones, essential oil and phlobatannins were absent.Table 2 is the antimicrobial activity of the leaf extract as compared to the standard antimicrobials. It could be said following the results above that the extract has activity against bacteria agents isolated such as Escherichia coli, Pseudomonas aeruginosa, and Staphylococcus aureus with no activity against fungal agent such as Candidaalbican.The result from table 3 above shows a dose dependent significant increase in analgesic activities that is the higher the dose, the greater the analgesic activity and vise visa.

A dose dependent anti-inflammatory activity of the extract is shown in table 4 above. The extract at both $1200 \mathrm{mg} / \mathrm{kg}$ and $400 \mathrm{mg} / \mathrm{kg}$ when compared with the control and reference shows no significant $(\mathrm{p}>0.05)$ anti-inflammatory activity. The percent inhibition for the extract was found to be highest at 60 minutes and afterwards decreases. The above results from table 5 shows that the ethanol extract of Costus afer leaves posses CNS activity evidenced in its increase in spontaneous locomotors activities. Table 6 above shows that ethanolic extract of Costus afer leaves posses CNS activity evidenced in its increase in the duration of the phenobarbitone induced hypnosis in albino mice. The extract at both $1200 \mathrm{mg} / \mathrm{kg}$ and $400 \mathrm{mg} / \mathrm{kg}$ when compared with the control and reference showed significant $(\mathrm{p}<0.05)$ phenobarbitone induced hypnotic activity. From table7, it can be seen that the extract does not have any significant effect on the HB, PCV and RBC, whereas a dose dependent significant decrease was noted in WBC, Platelet, neutrophill and lymphocyte. The above table also shows that Costus afer leaf extracts exert a dose dependent increase in clotting time of the blood of albino mice.

\section{Discussion}

In Nigeria many indigenous plants are used as spices, food or medicine. These plants often exhibit a wide range of biological and pharmacological activities. Extracts from the roots, leaves, barks, seed and fruits of these plants are used in traditional medicines as cough suppressant, analgesic, and CNS depressant and in the treatment of oxidative related disease (Okwu, et al, 2005). Generally, the active constituents contributing to these activities are the phytochemical constituents, vitamins and minerals (Okwu, et al, 2005). Phytochemicals are natural bioactive compounds found in plants. Phytochemicals are divided into two groups; primary and secondary compounds. These classes are according to their functions in plant metabolism. Amino acids, sugars, proteins and chlorophyll are known as primary compounds while secondary compounds consists of alkaloid, terpenoids, phenollic compounds and many more (Krishnaiahet al , 2009). Phytochemicals constituents exhibit a wide range of biological effects resulting in their protective or disease preventive properties. The 
possible actions include: antioxidants, anti-microbial, anticoagulant, analgesic, anti-inflammatory effect and physical action (Uruquiaga and Leighton, 2000). An ethno botanical survey of the genus Costus revealed that the ethanolic leaf extract of costus afer Ker Grawl contains potent biological active compounds which have antiinflammatory, analgesic, antimicrobial and anti-convulsant activities (Anyasor, et al, 2010a).

The present study investigated the phytochemical constituents, antimicrobial, CNS depressants, analgesic, anti-hemorrhagic, clotting time and anti-inflammatory activities of ethanol extract of Costus afer leaves. In the present study, the qualitative phytochemical analysis of the costus afer leaf extract shows the presence of alkaloids, saponins, flavonoids, tannins, phenols, glycosides and terpenoids. This is in line with the previous works (Ukpabi, et al, 2012a). However, report of Ukana et al indicates that the ethanolic extract of Costus afer leaves contains protein and carbohydrates (Ukana, et al, 2012). Alkaloids are known to have antiinflammatory, anti-microbial, analgesic, anti-convulsant and anti-hemorrhagic effects (Okwu, et al, 2005), as well as anti-hypertensive agent (Soforowa, 2009) while tannins have been found to have healing effect (Okwu, et al, 2005). Flavonoids, saponins and phenols are potent water soluble antioxidant which prevents oxidizing cells damage suggesting anti-inflammatory properties. The therapeutic potential of antioxidants in controlling degenerative diseases with marked oxidative damage from reactive oxygen species or free radicals have been reported (Anyasor, et al, 2010b).However following the above antimicrobial susceptibility testing results obtained, it could be said that ethanolic leaves extract of Costus afer has antimicrobial activities against Escherichia coli, Pseudomonas aeruginosa and Staphylococcus aureus but the extract is resistance against candida albican. This is in line with the previous work (Ukpabi, et al, 2012b).

The result of the analgesic activities of ethanoliccostusafer leaves reveals that the extract has analgesic activities in albino mice. This is in agreement with the previous work done by (Nwosu, et al, 2014). The reaction time increases from zero (0) minutes to 120 minutes and increase in reaction time in seconds was used as the unit for measurement of pain and an increase reaction time was indicative of analgesia. However, Momoh, et al, (2011) had reported that Costus afer contain phytochemical substances including alkaloids, flavonoids, tannins, phenols, glycoside and terpinoids, some of which have been implicated in antinociception. Costusafer extract may have achieved these antinociceptive effects by inhibiting the activity of cyclooxygenases-2 (cox-2) enzyme, causing the stoppage of prostaglandins formation. Prostaglandins are chemical substances which stimulate the nocireceptor in the body leading to the sensation of pain (John, et al , 1999). Previously, It has been observed that tannins, flavoniods and steroidal compounds posses good analgesic activity by inhibiting prostaglandins synthesis (Ramadan et al 1994; Ramaswam et al 1985)

Following the results obtained in the evaluation of the anti-inflammatory activities of the ethanol leaves extract of costus afer, it could be said that Costus afer extract has dose dependent anti-inflammatory activities. The activities increase as the dose increases and hence $1200 \mathrm{mg} / \mathrm{kg}$ has a higher activity than $400 \mathrm{mg} / \mathrm{kg}$. The anti-inflammatory activities increases from zero (0) minute to 60 minutes after which the activities decreases. This agrees with the previous work of (Nwosu, et al, 2014).It was also shown from the results obtained above that ehanolic extract of costus afer possesses spontaneous locomotors activities in albino mice and as well increases the duration of the phenobarbitone induced hypnosis in albino mice. This was also in line with the previous work done (Nwosu, et al 2014; Ezejiofor et al 2011). The activities increase with an increase in the dose and this is an indicative of the CNS depressant effect of the extract on the mice.

Evaluation of the ethanolic Costus afer leaves extract also shows that the extract increases the bleeding time (blood clotting time) of albino mice and this increase in clotting time was dose dependent as can be seen in table 6 . Hence, the clotting time of the dose of $1200 \mathrm{mg} / \mathrm{kg}$ is higher than that of $400 \mathrm{mg} / \mathrm{kg}$. The hematological evaluation of the leaves of Costus afer shows that the extract has no noticeable effect on the hemoglobin, packed cell volume and red blood cell components of the blood of albino mice but decreases the white blood cell, platelet count, neutrophils and lymphocytes components of the blood of albino mice. The decrease in platelet component of the blood of albino mice as shown corresponds to the increase in clotting time as shown above. This is because platelet is essential in the clot formation and a decrease in platelet count will increase the clotting time while an increase in platelet count will decrease the clotting time. This is similar with the report by Ezejiofor et al (2011).

\section{Conclusion}

From the above studies, it can be concluded that ethanolic leave extract of Costus afer ker Gawl possess antimicrobial, analgesic, anti-inflammatory and CNS depressant activity. Costus afer may be of value in the management of all forms of arthritis, rheumatism and other conditions associated with pain and inflammation as well in the treatment of microbial infections.

\section{References}


[1]. Anyasor G.N., Ugwu M.F., Ozo O.K.,(2010a). Biological properties of Costus afer leave. Journal of Ethano pharmacology, 9(1): 711.

[2]. Anyasor G.N., Ogunwenmo K.O., Olatunji A.O., Blessing E.A.(2010b). Phytochemical, proximate and mineral element composition of stem of Costus afer (Bush cane). Asian Journal of plant science and research. 2(5): 607-612.

[3]. Bland, S.M., Taylor D.O., Nduka M.O., Joke A.P., (2001). Investigations of the methanolic leaf extract of Costus afer Ker for pharmacological activities . Asian journal of science .4: 10-14.

[4]. Dandiya, P.C. and Columbine, H.J. (1991).Pharmacology experiment and therapeutics.125-153.

[5]. Ezejiofor A.N., Maduagwuna C.A., Okorie O, Chigbu L.N.,(2011).CNS depressant studies on methanolic extract of Adenant herapavonina seed. US-china medical science, 8:552-559.

[6]. Harbone, F.O., Charles E.O., Savic H.E,(1998). Phytochemicals of medicinal plants. India Journal of Pharmacology, 4(4): 45-47.

[7]. Iwu, M.M. (2009). Traditional Igbo Medicine Applied Sciences. Institute of Africa Studies Publicastion, University of Nigeria, Nsukka. 3(4): 21-25

[8]. John, A.O., Ezike E.O., Oko B,I., (1999).Anti-nociceptive properties of Costus afer leaves. PubMed central, 15(4): 7-12.

[9]. Krishnaiah,T.U., JesicaF.O., Marck, U.P.,( 2009). Some phytochemicals of medicinal plants. Science Alert.23:12-19.

[10]. Momoh, C.P., Cuss,E.G., Mark, I.O., ( 2011). Phytochemicals of some Nigerian medicinal plants. Plants resources of Tropical African in Medicinal Plants, 2: 16-21.

[11]. Nduka G.A., Onajobi F., Efere M.O., (2014). Anti-inflammatory and antioxidant activities of Costus afer Ker Gawl. Hexane leaf fraction in arthritic rat models. Journal of ethno pharmacology. 8: 543-551.

[12]. Nduka G.A., Ogunwenmo, B.E., G.N.,(2010).Phytochemical constituents and antioxidant activities of aqueous and methanolic extracts of Costus afer Ker Gawl.(Costaceae). Journal of investigational biochemistry. 9(31): 4880-4884.

[13]. Nwosu F.O., Okega S.A., Chuck M.T., (2014). Biological properties of some medicinal plants. Journal of Ethano pharmacology, 6: $2-6$

[14]. Okwu S.A., Chijioke C.O., Mmadu O.E.(2005). Important therapeutic properties of medicinal plant. Comprehensive Journal Of Medicinal Science. 2(2):4-9.

[15]. Oliver B. Medicinal plants in Nigeria, Nigerian college of Arts, Science and Technology Ibadan,University Press Nigeria. 1960.

[16]. Ramadam A., Harraz FM., and El-Mougy SA.(1994) Anti-inflammatory,analgesic andantipyretic effects of the fruit of Adansoniadigitata. Fitoterapia 65; 481-422

[17]. Ramaswam S., Pillai NP.,Gopalkrishnan V., Parmar NS and Ghosh MN. (1985). Analgesic effect of O( $\beta$-hydroxyethyl)rutoside in mice. Indian J. Exp. Biol. 23:219.220.

[18]. Saluja A. k., Santani D.D., (1994).Pharmacological investigations on the ethanolic extract of defatted pulp of xerotaphisspinosa. 65:153-157.

[19]. Sofowora M.O.,(2006). A text book on medicinal plant. Fift edition. P 45-52.

[20]. Trease, G.E., Evans, W.C. (1996). Pharmacognosy, 4th Edition, W.B. Sounders, USA, Pp.243 283.

[21]. Ukpabi A.K., Eze R.H., Ugwu E.C., (2012a). Chemical component of Costus afer plant. International Journal of Pharmatech Research, 4(2):7-10.

[22]. Ukpabi C.F., Agwu D.A., Ndukwe O.K., Agbafork.N., Nwachukwu S.N., (2012b). Phytochemical composition of Costus afer extract and its alleviation of carbon tetrachloride - induced hepatic oxidative stress and toxicity. International journal of Modern Botany. 2(5): 120-125.

[23]. Uruquiaga V.O., Leighton D.O.,( 2000). Biological effects of medicinal plant. Journal of Scientific Research And Development, 3(2):14-18.

[24]. Wall F.O., Satch F.O., Duff S.P., (1952,1954). Phytochemical analysis of Costs afer leaves. British Journal Of Pharmaceutical Research. 2(2):3-7. 